\author{
Aleksandra Wysokińska \\ Katedra Socjologii Sztuki \\ Uniwersytet Łódzki \\ ola.wysokinska@gmail.com
}

\title{
Hejtowanie hejterów, czyli jak radzimy sobie z mową nienawiści w internecie
}

Pojęcie „hejt” wdarło się jakiś czas temu szturmem do powszechnej świadomości, robiąc karierę $\mathrm{w}$ dyskursie medialnym, a w dalszej kolejności wkraczając również w obszar zainteresowań badaczy: socjologów, lingwistów czy medioznawców. Bez wątpienia jest to jedno z najczęściej powtarzanych haseł ostatnich miesięcy, jak jeszcze niedawno selfie czy gender. Miejscem jego powstania i powszechnego występowania jest internet, ale jak to zwykle bywa, można zauważyć obecność hejtu również w tradycyjnych mediach.

Rozważania nad hejtem warto zacząć od pochylenia się nad genezą samego sformułowania. Jak większość nowych słów pojawiających się w języku polskim w ostatnim ćwierćwieczu i to jest anglicyzmem - stanowi fonetyczną formę słowa hate, które możemy tłumaczyć zarówno jako „nienawiśc”, jak i „nienawidzić”. Sama historia zadomowienia się hejtu w naszej mowie ojczystej jest bardzo ciekawa i zasługuje na uwagę, pokazuje bowiem pewne mechanizmy i reguły rządzące językiem, a także sposoby jego przekształcania przez użytkowników. Słowo hate, o ile występuje samodzielnie, w interesującym nas przypadku jest częścią sformułowania hate speech, którą tłumaczymy na polski jako „mowę nienawiści”. Rodzime sformułowanie jest znane i używane od dawna, posiada swoją precyzyjną 
definicję, ale nigdy nie zrobiło wyjątkowej kariery, szczególnie jeśli mówimy o dyskursie medialnym. Można przypuszczać, że stało się tak za sprawą jego długości i nieprzyjemnej wymowy. Zupełne przeciwieństwo stanowi hejt, które jest hasłem krótkim i łatwym do wypowiedzenia, a więc odpowiada dążeniu do ekonomizacji języka. Jak zauważył językoznawca Jerzy Bralczyk, słowa zawierające cząstkę „ej” czy „aj” nie stanowią problemu dla użytkownika, co również częściowo tłumaczy dużą popularność słowa „lajk” (Bralczyk, Mikuła, Witt 2015).

Należy jednak pamiętać, że wspomniane pojęcia nie są tożsame. Kwestie związane $\mathrm{z}$ agresją internetową interesowały badaczy na długo przed wybuchem medialnej histerii, jakiej świadkami jesteśmy obecnie. Poza najbardziej rozpowszechnionym pojęciem hate speech stosowano takie określenia, jak: agresja elektroniczna (Pyżalski 2012), mowa agresji (Bauer 2009), język wrogości (Kuźmiński 2012) czy wredna mowa (Janicki, Władyka 2014). Mając za wzór teksty naukowe poruszające tę tematykę pozwolę sobie przytoczyć jedną z wielu definicji mowy nienawiści. Wspomnę jedynie, że wielość nie przekłada się na drastyczne różnice w rozumieniu terminu - elementy konstytutywne pozostają te same. Według Nijakowskiego:

mowa nienawiści polega na przypisywaniu szczególnie negatywnych cech lub wzywaniu do dyskryminujących działań wymierzonych w pewną kategorię społeczną, przede wszystkim taką, do której przynależność jest postrzegana jako „naturalna” (przypisana), a nie z wyboru. (Nijakowski 2008 za: Włodarczyk 2014: 123)

Autor wyróżnia również wyznaczniki, takie jak: uwłaczająca leksyka, dehumanizacja oraz podmiot działan - ważnym elementem jest przypisany charakter obrażanej zbiorowości - zatem będą one dotyczyły mniejszości seksualnych, narodowych czy wyznaniowych. Nie uwzględnia się tutaj obraźliwych wypowiedzi dotyczących sfer, na które mamy wpływ, np. poglądy polityczne. Jak widać, nie wszystkie agresywne zachowania w internecie można włączyć do tego katalogu. Istnieje cały szereg dewiacyjnych zachowań podczas wirtualnych dyskusji polegających na: „używaniu obelżywego języka, pogardliwej ocenie różnych zjawisk, znieważaniu zarówno rozmówców, jak i różnych innych podmiotów oraz na wyrażaniu agresji i nienawiści pod ich adresem" (Juza 2015: 29). Wydaje się, że właśnie z potrzeby ich nazwania zaadaptowano pojęcie hejtu, w zasadzie tożsame $\mathrm{z}$ mową agresji. Można jednak odnieść wrażenie, że niekiedy wprowadza ono dodatkowy zamęt. Niektórzy bowiem postulują stosowanie tego terminu wobec wypowiedzi agresywnych i przekraczających granice kultury wypowiedzi, ale jednak niemożliwych do sklasyfikowania jako mowa nienawiści (Włodarczyk 2014: 124), zaś w języku potocznym funkcjonuje ono raczej jako pojęcie nadrzędne, zawierające $\mathrm{w}$ sobie hate speech. Słowna agresja jest (wbrew pozorom) dość złożonym 
problemem, szczególnie jeśli przyjrzymy się słowom traktowanym w pewnych kręgach jako obraźliwe. Jak bowiem zareagować na określanie kogoś gejem albo Żydem po to, by go zelżyć (Bauer 2009: 48)? Można też zaobserwować, że wraz z rosnącą popularnością pojęciem hejterstwa określane są kolejne rodzaje wypowiedzi, co sprawia, że jego granice stają się coraz bardziej rozmyte. Prowadzi to niekiedy do absurdalnych sytuacji, w których trzeba uważać na każde swoje słowo w emocjonalnych internetowych dyskusjach, by nie zostać oskarżonym o hejtowanie.

Ten etymologiczny wstęp jest o tyle konieczny, że jak głosi prawo relatywizmu językowego: używany język wpływa w pewnym stopniu na nasz sposób myślenia, postrzegania świata, a co za tym idzie, działania (Klimczuk 2013). Myślę, że analiza zjawiska hejtu pokazuje, że w tym przypadku teoria znajduje odzwierciedlenie w rzeczywistości. Moje spostrzeżenia są bowiem następujące: dopóki posługiwaliśmy się określeniem „mowa nienawiści”, które nie było popularne, świadomość istnienia zjawisk określanych tym mianem była dość niska, nie wspominając już o ewentualnych działaniach zapobiegawczych. Kiedy zaś ukuto hasło „hejt” i zostało ono zaadaptowane przez media głównego nurtu, doświadczyliśmy niemal eksplozji zainteresowania zachowaniami wpisującymi się w jego definicję. Co więcej, z czasem zauważamy poszerzanie ich katalogu, co może prowadzić do niechcianych konsekwencji. Oczywiście nie należy rozpatrywać tej kwestii jednowymiarowo i zapewne istnieje szereg innych czynników decydujących o takim rozwoju sytuacji, aczkolwiek uważam, że aspekt "praktyczno-językowy” odegrał tu znaczącą rolę. Warto w tym miejscu dodać, że nowo powstałe słowo bardzo łatwo poddaje się odmianie i dalszemu słowotwórstwu zgodnie z zasadami języka polskiego. O ile w przypadku „mowy nienawiści” trudno było o dobrze brzmiące określenie czynności („szerzenie mowy nienawiści” brzmi zbyt oficjalnie i jest jeszcze dłuższe) czy agenta/sprawcy („nienawistnik” jest nieprecyzyjne i nie oddaje istoty rzeczy), to zgrabny anglicyzm rozmnożył się szybko w całą grupę wyrazów, na czele $\mathrm{z}$ „hejterem” $i$ „hejtowaniem”, co przyczyniło się do dalszego wzrostu popularności terminu.

Rodzi się zatem pytanie, na ile słuszne jest poświęcanie tak dużej uwagi omawianemu zjawisku. Czy faktycznie polski internet pełen jest nienawistników pragnących jedynie obrazić swoich interlokutorów? Czy rzeczywiście mamy do czynienia z rzeką wypowiedzi: „radykalnych, kategorycznych, fanatycznych, obraźliwych i formułowanych bez żadnych merytorycznych uzasadnień" (Juza 2015: 30)? Kwestia jest o tyle złożona, że możemy mówić o dwóch wymiarach istnienia hejtu w internecie: widoczności i skali. Badania wyraźnie pokazują, że na mowę agresji w największym stopniu narażeni są młodzi ludzie, w tym uczniowie i studenci (Feliksiak 2007: 2). Z badań przeprowadzonych przez Fundację Dzieci Niczyje wynika, że $40 \%$ młodych ludzi w wieku 14-17 lat spotkało się w sieci z przejawami mowy 
nienawiści, głównie w postaci obraźliwych komentarzy czy dyskusji na forach (Włodarczyk 2014: 124-125). Kiedy jednak próbowano sprawdzić, z jaką ilością tego typu wypowiedzi mamy faktycznie do czynienia, okazało się, że w 10-milionowej próbie stanowily one raptem 0,86\% (Troszyński 2011 za: Jonak 2012: 58). Inne badania mówią o liczbie nie większej niż 2,5\%, jednak autorzy podkreślają, że liczba ta jest wyższa, jako że kryterium były wszystkie treści obraźliwe (Jonak 2012: 58). W wartościach bezwzględnych jest to nadal duża ilość, jednak biorąc pod uwagę ogromną skalę cyfrowej komunikacji, problem nie wydaje się już tak znaczący. Wart uwagi jest tutaj inny, szerszy problem: fakt, że wyrażanie negatywnych emocji oraz pesymizm są istotnymi elementami internetowych dyskusji (Jonak 2012: 58). Zatem jedni autorzy postulują, by dostrzegać faktyczne rozmiary problemu i doceniać ogromną skalę pozytywnych zjawisk w sieci, inni zaś twierdzą, że hejt jest częścią tzw. kultury obrażania, która objawia się m.in. w publicznych kłótniach (na tematy czysto osobiste) czy zakładaniu hate page’y (będących przeciwieństwem fanpage’y) tworzonych zarówno przeciwko znanym osobom, jak i rówieśnikom (Włodarczyk 2014).

Dalsze konsekwencje były łatwe do przewidzenia: w myśl zasady, że każda akcja rodzi reakcję, pojawienie się hejtu w świadomości społeczno-medialnej doprowadziło w niedługim czasie do potrzeby jego zwalczania. Do walki z mową nienawiści pod nowym szyldem przystąpiły zarówno instytucje medialne, organizacje społeczne, jak i indywidualni internauci. Wykorzystywane są różne sposoby, zarówno te tradycyjne, jak i bardziej twórcze, jednak jedno jest pewne: wszyscy jednoczą się w działaniach przeciwko negatywnym zachowaniom w sieci. To o tyle interesujące, że mowę nienawiści, w różnych odmianach i stopniach intensywności, można uznać za immanentną cechę internetu, a hejtowanie postawić obok takich działań jak trolling ${ }^{1}$ czy flame wars ${ }^{2}$ jako specyficzny element jego kultury. Doświadczeni użytkownicy najczęściej potrafią radzić sobie z tymi zjawiskami, zazwyczaj po prostu ignorując autora, stąd też wzięło się sformułowanie „nie karmić trolla”. Badania prowadzone wśród młodzieży pokazują, że mowa agresji stanowi dla niej codzienność, co prowadzi do wypracowania sposobów radzenia sobie z nią, a najczęściej po prostu braku reakcji (Włodarczyk 2014: 155). Skupienie się

1 Funkcjonuje także pod spolszczoną nazwą „trollowanie”. „Działanie polegające na bezcelowym irytowaniu innych internautów, najczęściej uczestników dyskusji; opiera się na „zamierzonym wpływaniu na innych użytkowników w celu ich ośmieszenia lub obrażenia (czego następstwem jest wywołanie kłótni) poprzez wysyłanie napastliwych, kontrowersyjnych, często nieprawdziwych przekazów czy też poprzez stosowanie różnego typu zabiegów erystycznych" (Trollowanie b.r.).

2 Wroga, agresywna i bardzo emocjonalna dyskusja poruszająca kontrowersyjną kwestię. Celowo "podkręcana”, pojawiają się w niej obelgi i wulgaryzmy. Nie posiada polskiego odpowiednika poza „kłótnia internetowa”. 
mediów właśnie na hejterach spowodowało, że stali się oni bardziej widoczni, co wzbudziło potrzebę przeciwstawienia się im. Ważną kwestią jest również sensowność czy skuteczność działań zapobiegawczych, które opierają się głównie na leczeniu objawów, a nie sięganiu do przyczyn patologicznych, aspołecznych zachowań w sieci. Z wypowiedzi młodych ludzi wynika bowiem, że przekazy edukacyjne, najczęściej przybierające formę kampanii społecznych, stanowią odrębną narrację od internetowej codzienności, a ewentualne zmiany zachowania następujące pod ich wpływem mają często charakter pozorny lub powierzchowny (Włodarczyk 2014: 155). Jednak bez względu na towarzyszące wątpliwości warto poświęcić nieco uwagi analizie sposobów działania osób starających się oczyszczać internet z negatywnych emocji, czym właśnie chcę się zająć w niniejszym artykule.

Zanim przejdę do opisu i analizy poszczególnych przypadków chciałabym poczynić bardzo istotne, w moim odczuciu, zastrzeżenie. Mówiąc o hejcie w sieci, musimy przede wszystkim nauczyć się odróżniać jego przejawy. Internet jest specyficznym medium, które rządzi się swoimi zasadami, niekiedy zupełnie różnymi od tych, które znamy z tradycyjnych form przekazu czy komunikacji bezpośredniej. Wynika to zarówno z nowego sposobu porozumiewania się, łączącego cechy mediów masowych i komunikacji twarzą w twarz, jak i ze struktury użytkowników ${ }^{3}$. O ile dostęp do sieci posiada już niemal połowa świata ${ }^{4}$, to twórcy nadal stanowią niewielki odsetek internautów, a to oni kształtują klimat funkcjonowania. Sprawia to, że w wirtualnych interakcjach ceni się czarny humor i ironię, a dowcipne docinki są raczej wyrazem sympatii niż negatywnych emocji. Internet, a w szczególności serwisy opierające się na tzw. social bookmarking $u^{5}$ i dyskusji, cenią sobie swobodę wypowiedzi, która nie powinna być krępowana polityczną poprawnością. W ostatnim czasie jesteśmy świadkami niemalże histerii medialnej na punkcie hejtu, co sprawia, że doszukujemy się przejawów nienawiści w prawie każdej krytycznej wypowiedzi. Jest to zjawisko o tyle niebezpieczne, że może w dalszej konsekwencji prowadzić do cenzury w imię obrony naszej delikatnej samooceny. Należy jasno powiedzieć: mianem hejtu można określić jedynie te wypowiedzi, które w jednoznaczny sposób chcą obrazić adresata czy sprawić mu przykrość i jest to ich jedyna intencja. Przykłady przekraczania granic można mnożyć, jednak chciałabym przytoczyć

3 Wynikająca m.in. ze specyficznej struktury demograficznej: głównie młodzi ludzie z wykształceniem średnim lub policealnym (Portret internauty b.r.)

4 46,4\% według danych z listopada 2015 r., 88\% penetracji w Ameryce Północnej i 73,5\% w Europie (Internet World Stats b.r.).

5 W Polsce najpopularniejszym jest Wykop.pl, który gromadzi miliony aktywnych użytkowników, amerykańskim odpowiednikiem jest reddit.com. 
jeden, pochodzący ze świata nauki. W publikacji Mowa nienawiści - raport $z$ badań sondażowych (2014) wśród przykładów mowy nienawiści można znaleźć takie wypowiedzi internautów (oryginalna pisownia): „Tymczasem zakaz wejścia Romów nie wynika z tego, że oni są Romami tylko z tego, że ich zachowania zagrażało bezpieczeństwu innych gości więc ograniczono ich wejście na czyjś prywatny teren” lub „Dlatego też dla większości Polaków ludobójcze akcje skierowane przeciw nim ze strony współmieszkańców - Ukraińców podczas II wojny światowej, a zwłaszcza ze strony przyjaciół, dobrych sąsiadów, były całkowicie niezrozumiałe i niespodziewane, były czymś z czym do dziś nie mogą się pogodzić”.

Przechodząc do meritum: w toku gromadzenia informacji o kolejnych akcjach przeciwdziałających szerzeniu mowy nienawiści w internecie zaczęło wyłaniać się coś na kształt typologii, która poza prostym podziałem na inicjatywy indywidualne i instytucjonalne pozwala nieco uporządkować analizowane działania. Pozwoliłam sobie na dokonanie podziału na metody tradycyjne, ale (częściowo) dostosowane do reguł medium, w którym funkcjonują, oraz metody nowoczesne i niekonwencjonalne, których modus operandi jest zgodny z logiką działania internetu, gdyż niejako z niej wyrasta. Wśród tych pierwszych można wyróżnić przede wszystkim kampanie społeczno-edukacyjne, ale także współpracę $\mathrm{z}$ wymiarem sprawiedliwości (część działań definiowanych jako mowa nienawiści podlega karze na podstawie przepisów kodeksu karnego). Na drugą kategorię składają się głównie inicjatywy opierające się na ostracyzmie społecznym: próby wyśmiania, zdyskredytowania autorów obraźliwych wypowiedzi, cięte riposty czy obnażanie ich ignorancji. Niejednokrotnie wiąże się to z pełnym upublicznieniem wizerunku czy danych hejtera, co pozwala na jego identyfikację zarówno w sieci, jak i w świecie realnym. Oczywiście wyodrębnione przeze mnie kategorie stanowią raczej „typy idealne”, a analizowane przypadki mogą stanowić ich różnorakie połączenia.

\section{Przypadek nr 1 - kampania UNICEF One shot is enough}

UNICEF to organizacja działająca na rzecz dzieci i młodzieży i właśnie do nich kierowana jest ta inicjatywa. Ma ona za zadanie przeciwdziałać tzw. cyberbullyingowi $i^{6}$ poprzez uświadamianie najmłodszym użytkownikom smartfonów, jak niebezpieczne może być wkraczanie nowoczesnych technologii do życia. Pojęcie cyberbullyingu funkcjonuje w literaturze fachowej jako „bullying realizowany przy

6 Wirtualna forma znęcania się, często przyjmująca powtarzalny charakter. W USA funkcjonuje głównie w odniesieniu do dzieci i młodzieży szkolnej. 
użyciu nowych technologii informacyjnych, zwykle internetu i telefonów komórkowych" (Pyżalski 2012: 119), jednak nie pojawił się dotychczas żaden rodzimy odpowiednik, podobnie jak w przypadku cyberstalkingu, który opisuje pokrewny problem społeczny, nadal bardzo słabo rozpoznany w naszym kraju. Badacze zmagają się z trudnościami definicyjnymi, jednak bez wątpienia jest to zagadanienie o większej skali i zasięgu, generujące cały szereg patologicznych zjawisk, jakie nie mogłyby mieć miejsca bez wykorzystania globalnej sieci. Kampania ma formę wirtualnych plakatów przedstawiających najczęściej odnotowywane sytuacje znęcania się nad rówieśnikami. Kolejne odsłony ilustrują hasła „grubas”, „słabeusz” i „frajer” ("Fatty”, "Weak”, "Nerd”). Fotografie są monochromatyczne i utrzymane w mrocznej stylistyce, która podkreśla dramatyzm sytuacji. Wizerunki dzieci są bardzo wymowne i nasuwają jednoznaczne skojarzenia $\mathrm{z}$ najgorszymi formami przemocy fizycznej (patrz fot. 1). Jest to spójne z hasłem przewodnim, które możemy tłumaczyć jako „Wystarczy jeden strzał”. Słowo shot oznacza w angielskim zarówno strzał, jak i „pstryknięcie” zdjęcia, ale w tym przypadku językowa dwuznaczność została doskonale wykorzystana. Celem jest podkreślenie, że wykonanie i opublikowanie w sieci (czy rozpowszechnienie w innej formie) nawet jednego (np. kompromitującego) zdjęcia może oznaczać wyrok i złamanie psychiki dorastającego człowieka. Na ile jest to poważne zjawisko, nie trzeba przekonywać również w Polsce, kraju o dużo niższej dostępności internetu i nowoczesnych technologii niż w krajach anglosaskich. Latem 2015 roku media obiegła wiadomość o samobójczej śmierci czternastolatka, będącej skutkiem dręczenia chłopca przez rówieśników, zarówno „w realu”, jak i w sieci ${ }^{7}$ A niestety nie był to odosobniony przypadek i można się spodziewać, że nie ostatni tego typu, bowiem z badań przeprowadzonych przez Fundację Dzieci Niczyje wynika, że: „osoby, które miały kontakt z przekazami pełnymi nienawiści w sieci, wykazywały większą skłonność do depresji lub zachowań lękowych" (Włodarczyk 2014: 125).

\section{Przypadek nr 2 - kampania „HejtStop”}

Również na polskim gruncie pojawiło się kilka inicjatyw mających na celu zwalczanie mowy nienawiści, szczególnie w internecie. Jedną z nich jest akcja zatytułowana HejtStop. Zasłynęła w ostatnim czasie materiałami, których głównym bohaterem jest Jarosław Kuźniar, popularny dziennikarz telewizyjny, znany również ze

7 Źródło: http://www.tvp.info/20712085/jednego-w-rurkach-mniej-szydercze-profile-i-agresjawobec-14latka-ktory-popelnil-samobojstwo [dostęp: 13.02.2016]. 

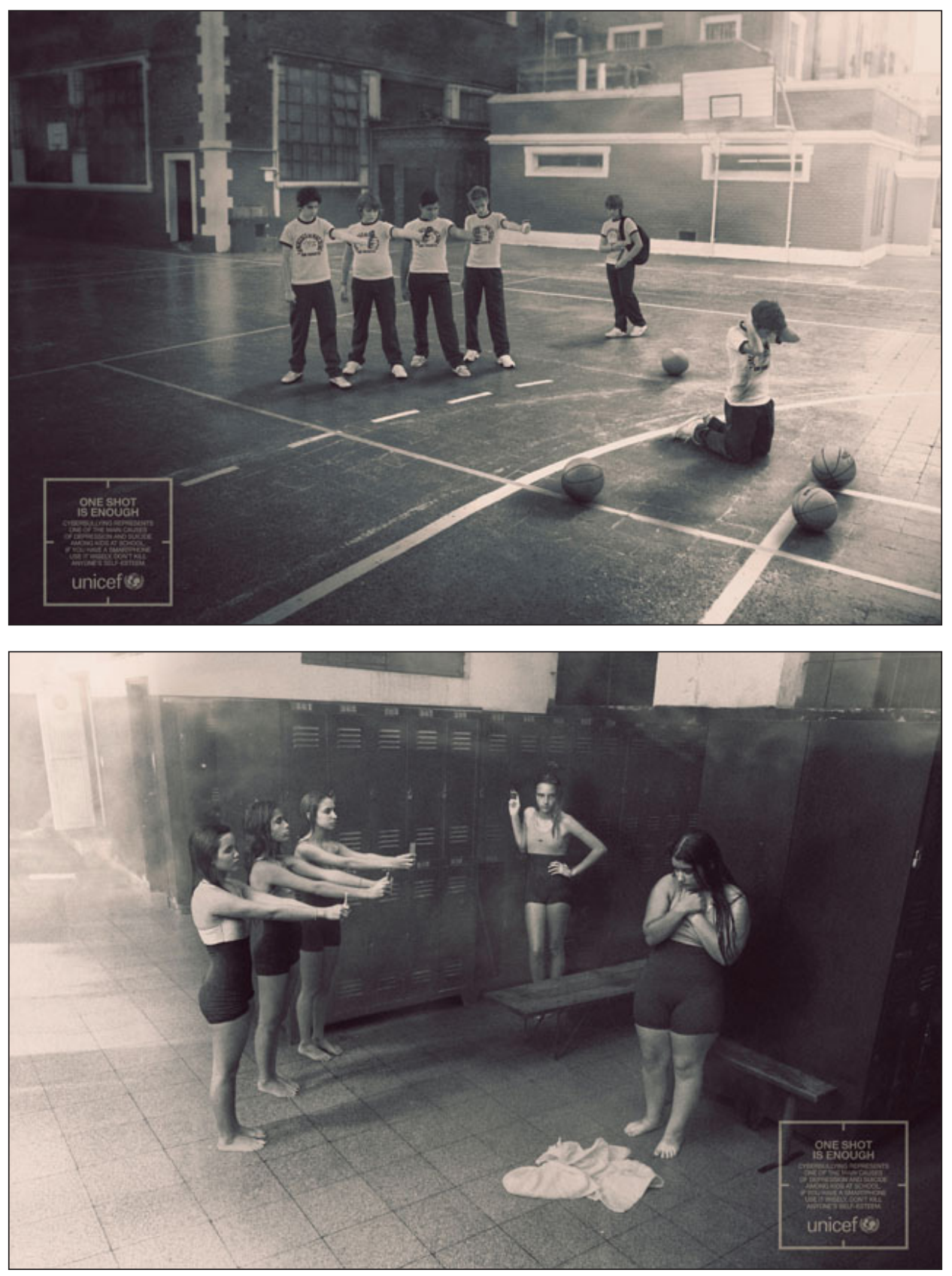

Fot. 1. Plakaty kampanii UNICEF One shot is enough źródło: http://www.cosmopolitan.pl/w-twoim-swiecie/5989/one-shot-is-enough-bardzo-mocna-kampania-unicef, 29.12.2015 
swojej aktywności w mediach społecznościowych. W gruncie rzeczy jest to jedyny do tej pory bardziej widoczny przejaw działalności twórców. Oczywiście istnieje strona internetowa, na której można znaleźć informacje na temat samego zjawiska oraz projektu i jego założeń. Istnieje również formularz służący do zgłaszania przejawów nienawiści na tle rasowym, płciowym czy wyznaniowym, ale można odnieść wrażenie, że są to elementy, którym twórcy poświęcili mniej uwagi ${ }^{8}$. Nacisk został położony głównie na kontrowersyjną akcję z nie mniej kontrowersyjnym dziennikarzem w centrum. Składają się na nią głównie materiał filmowy oraz grafiki, które są dostępne do pobrania na stronie internetowej. Identyfikacja w sieci ma miejsce za pomocą hasztaga \#ryjkuzniara, który dobrze konweniuje z pozostałą formą przekazu. Czterdziestosekundowy filmik stanowiący rdzeń kampanii ma dość prostą formę - przedstawia wizerunek Jarosława Kuźniara, wokół którego wyświetlają się obelgi kierowane do niego przez nienawistników. Jednocześnie zmienia się również wizerunek dziennikarza animowany metodą poklatkową. Charakteryzacja odpowiada kolejnym inwektywom pojawiającym się na ekranie: i tak twarz zostaje wzbogacona m.in. o tatuaż z sierpem i młotem, krwawą swastykę i gwiazdę Dawida na czole, pejsy czy tęczową flagę. Siłę przekazu podkreśla mocna elektroniczna muzyka, a na końcu widz odczytuje hasło: „Hejt w sieci to przemoc słowna. Zostawia trwały ślad”. Filmem udało się zainteresować wielu internautów i z pewnością cel kampanii został częściowo osiągnięty. Warto zwrócić uwagę na jeden, bardzo istotny fakt. Jak zauważyło wiele osób ${ }^{9}$, wykorzystanie wizerunku właśnie tej postaci można bez wahania nazwać hipokryzją, gdyż panująca wobec niej niechęć ma swoje źródło właśnie w postawie nietolerującej absolutnie żadnej krytyki. Dziennikarz wielokrotnie dawał się poznać jako człowiek agresywny, niekulturalny i wręcz pałający nienawiścią do wszystkich, którzy się mu sprzeciwiają. Kolejne ociekające jadem tweety obiegają regularnie internet (Jarosław K. - Król Hejterów 2015). Z tego względu kampania, o ile szlachetna $\mathrm{w}$ przekazie, skazała się na potępienie $\mathrm{w}$ wielu środowiskach.

8 Tym bardziej, że sam system zgłoszeń jest nieprzejrzysty i chaotycznie skonstruowany: na stronie widnieją dwie zakładki: „zgłoś hejta” i „zgłoszenia”, które wprowadzają zamęt. Do tego sam formularz nie działa poprawnie.

9 Patrz: Himalaje hipokryzji. Jarosław Kuźniar twarza kampanii „Hejt Stop” (2015); „Szanowny Panie Kuźniar Jest takie mądre powiedzenie; »pluł razy kilka... opluli i wilka « Nie usprawiedliwia to tych, którzy Pana obrażają, ale jest pan ostatnim, który powinien mieć o to pretensje" (Komentarz $\sim$ Zając (2015); „Promowanie się na robieniu z siebie ofiary $\wedge \wedge$ Gdyby nie hejt, to nikt by o nim nawet nie usłyszał :D” (Komentarz co ja widzę 0_o (2015). 
Warto w tym miejscu zastanowić się nad źródłami agresji werbalnej w sieci. Nie ulega bowiem wątpliwości, że przekazy medialne mają duży wpływ na sposób naszego funkcjonowania w internecie, szczególnie jeśli mówimy o najmłodszych użytkownikach. A przypadek Jarosława Kuźniara jest tylko jednym z wielu ilustrujących stwierdzenie, że przykład idzie z góry. W raporcie CBOS na temat społecznej percepcji przemocy werbalnej (2007) widać wyraźnie, że w opinii badanych osoby publiczne bardzo często uciekają się do zachowań, które tak bardzo próbujemy tępić - wśród nadawców obraźliwych komunikatów najczęściej wskazywani byli politycy (49\%) oraz członkowie organizacji ideologicznych (44\%). Przy konstruowaniu kolejnej kampanii społecznej może warto się zastanowić, na ile będzie ona skuteczna w sytuacji, gdy firmują ją osoby (uznawane niekiedy za autorytety), których praktyki można uznawać za naganne lub warte napiętnowania.

\section{Przypadek nr 3 - materiał wideo You look disgusting}

Przypadek, który chcę omówić w dalszej kolejności, nie jest kampanią sensu stricto, ale ma zbliżoną, tradycyjną w formie konstrukcję, posługuje się też podobną poetyką, a ponadto jego celem jest edukowanie, uświadamianie widzów. Dlatego zdecydowałam się umieścić go właśnie w tym miejscu. I tutaj mamy do czynienia $\mathrm{z}$ materiałem wideo, ale został on stworzony przez jedną osobę - vlogerkę o nicku My Pale Skin, prowadzącą kanał na YouTube. Jak opisuje sama autorka, zdecydowała się na nagranie filmiku w odpowiedzi na skrajne komentarze internautów pojawiające się od czasu, kiedy zaczęła prezentować swój „prawdziwy” wizerunek. W największym skrócie: dziewczyna zajmuje się instruowaniem, jak wykonywać makijaż, zatem zazwyczaj wygląda niezwykle atrakcyjnie. Jednak jakiś czas temu zdecydowała się zacząć pokazywać swoją twarz bez makijażu, a ponieważ cierpi na poważne problemy skórne, różnica jest ogromna. Od tego czasu kanał My Pale Skin zalała fala hejtu, widzowie wyrażali się na temat jej wyglądu w najgorszych słowach, a do tego zarzucali oszustwo (dokonywane za pomocą makijażu). W konsekwencji powstał film, w którym zestawione są te dwa wizerunki wraz z komentarzami o skrajnym wydźwięku, ukazane jest również cierpienie i emocje targające vlogerką (You look disgusting 2015). Bezpośredni przekaz (wynikający z końcowego hasła) głosi, by czuć się piękną bez względu na to, co mówią inni. Jednak wykorzystanie w takiej formie komentarzy internetowych nienawistników sprawia, że materiał można umieścić w kategorii przeciwdziałających hejtowi. 


\section{Przypadek nr 4 - serwis Zgłoś Nienawiść}

Kolejna inicjatywa przenosi nas na grunt nieco poważniejszy niż tylko próba uświadamiania hejterów, bowiem pozwala ona podejmować kroki prawne wobec nich. Serwis Zgłoś Nienawiść ${ }^{10}$ powstał z inicjatywy Stowarzyszenia przeciw Antysemityzmowi i Ksenofobii „Otwarta Rzeczpospolita”, której głównym celem jest: „krzewienie postawy otwartości i szacunku dla osób i grup o odmiennej identyfikacji etnicznej, narodowej, religijnej, kulturowej lub społecznej oraz przeciwdziałanie wszelkim formom rasizmu, antysemityzmu, ksenofobii i innym postawom godzącym w godność człowieka"11. Pozwala na zgłaszanie aktów ściganych prawem w taki sposób, by organizacja mogła podjąć wobec ich autorów dalsze kroki. Oczywiście nie jest to możliwe w każdym przypadku, musimy bowiem dysponować konkretnymi danymi. Przy zgłoszeniu zobowiązani jesteśmy do podania daty i miejsca wydarzenia, opisu czynu (np. cytatu z czasopisma lub strony internetowej), atakowanej osoby, typu incydentu (do wyboru z kilku kategorii, głównie związanych z mową nienawiści i dyskryminacją na tle rasowym, wyznaniowym itp., ale także propagowaniem totalitarnego ustroju państwa); możemy też opatrzyć go dodatkowym opisem i wzbogacić plikami, a także zaznaczyć na mapie. Jeśli mamy wątpliwości co do skuteczności działań, pomoże je rozwiać baza incydentów, wraz z podziałem wedle stopnia zaawansowania sprawy. Nieco martwi fakt, że większość zgłoszeń nie przynosi wymiernych skutków, gdyż następuje: „odmowa wszczęcia dochodzenia wobec braku znamion czynu zabronionego", ale pokazuje to dobrze ułomność polskiego prawa wobec aktów przemocy werbalnej. Jednak dla osób chcących przeciwdziałać hejtowi mimo przeciwności serwis dostarcza bazę ekspertyz prawnych i językowych, których autorzy: „proponują efektywne narzędzia analizy i interpretacji przejawów dyskryminacji” ${ }^{12}$. Za pośrednictwem strony uzyskujemy też dostęp do wzorów zawiadomień i zażaleń, a także do „Poradnika obywatela” doradzającego jakie kroki podejmować w zetknięciu się z mową nienawiści. Ostatnim elementem serwisu jest zbiór dobrych praktyk, na który składają się rodzime i zagraniczne inicjatywy przeciwdziałające problemom społecznym, niekoniecznie skupiające się jedynie na hejcie.

10 Serwis dostępny pod adresem: http://zglosnienawisc.otwarta.org/. 


\section{Przypadek nr 5 - wpis administracji Wykop.pl}

W kontekście podejmowania kroków prawnych warto wspomnieć o sytuacji, jaka miała miejsce kilka miesięcy temu — pozornie była nieistotna, ale odbiła się głośnym echem w polskim internecie. Chodzi o wpis administracji serwisu Wykop.pl na tzw. mikroblogu. Autorzy zauważali w nim, że są od pewnego czasu wręcz: „Zasypywani żądaniami wydania danych osób, które w swych komentarzach jawnie nawołują do nienawiści i agresji przeciwko innym ludziom i grupom ludzi”13 i nie mają możliwości w takiej sytuacji odmówić i stanąć w obronie użytkownika, a niekiedy po prostu nie widzą do tego powodów. Oświadczenie kończy wymowne stwierdzenie: „I pamiętajcie: w sieci nie jesteście anonimowi” ${ }^{4}$, które najwyraźniej bardzo poruszyło niektórych internautów, czy też dało im do myślenia. Nie wszyscy mają bowiem świadomość, że nawet jeśli publikują swe wypowiedzi w sieci pod anonimowym nickiem, zazwyczaj nie stanowi problemu dotarcie do prawdziwych danych. Pozostała treść oświadczenia również wywołała wiele emocji, nie tylko wśród „wykopowiczów”. Wiele osób pochwalało taką postawę administracji, ale pojawiały się też wątpliwości m.in. związane z ograniczaniem swobody wypowiedzi przez polityczną poprawność ( Wykop.pl nie będzie tolerował... 2015).

Warto w tym kontekście wspomnieć, że właśnie anonimowość jest wymieniana jako jedna z głównych przyczyn mowy agresji, chociaż, jak pokazują tego typu sytuacje, jest ona pozorna. Badacze jednak zwracają uwagę na fakt, że w przypadku komunikacji internetowej łamiąca normy osoba nie jest identyfikowalna dla innych w momencie rozgrywania się sytuacji interakcyjnej. Kluczowa jest zatem nie tyle faktyczna anonimowość, co wrażenie, że jest się anonimowym (Juza 2015: 38). Wpływa ono na zmniejszenie zahamowań, podobnie jak brak fizycznej obecności interlokutora zmniejszający wyraźnie stopień konformizmu wobec norm społecznych (Wallace 2003: 85).

\section{Przypadek 6 - wpisy na fanpage'u Tedego}

Zupełnie inną taktykę walki z hejterami przyjął znany polski raper Tede. Najwyraźniej uznał on, że "pokojowe” metody polegające głównie na uświadamianiu i edukowaniu nienawistników nie są wystarczające i nie przynoszą oczekiwanych

13 Źródło: http://www.wykop.pl/wpis/14426931/wykopowicze-od-pewnego-czasu-jestesmy-zasypywani-z/ [dostęp: 31.12.2015].

14 Tamże. 
skutków, należy więc podjąć działania, które będą faktycznie godzić w osoby szerzące hejt w internecie. Oczywiście akcję zrealizował we właściwym sobie stylu, tak by nie służyła tylko ukaraniu sprawców, ale przysporzyła też jemu i fanom nieco zabawy. Sięgnął on do profili osób publikujących na jego fanpage’u obraźliwe, wulgarne komentarze i pobrał z nich zdjęcia, które wyraźnie przedstawiają wizerunki hejterów, a następnie zestawił je z odpowiednimi cytatami i umieścił na Facebooku i Instagramie. Wpisy oznaczał hasztagiem \#zobacz_mojego_hejtera, zapowiadając, że na kilku publikacjach się nie skończy. Jak można było się spodziewać, autorzy hejtu stali się przedmiotem bezlitosnej krytyki ze strony fanów rapera. Wśród komentarzy można było też dostrzec deklaracje o znajomości nienawistników i przykrych konsekwencjach, jakie mogą ich spotkać w realnym świecie. Akcja zakończyła się równie szybko, co rozpoczęła - po kilku wpisach opublikowanych w krótkim czasie (większość jednego dnia), nie pojawiły się kolejne. Co więcej, część już zamieszczonych zdjęć została usunięta (możliwe, że Tede został zmuszony do tego przez administratorów Facebooka lub osoby, których wizerunki publikował). W pierwszym odruchu cieszy podjęcie bezwzględnych kroków, ale po dłuższym zastanowieniu inicjatywa wydaje się jednak wątpliwa moralnie. Można zadać pytanie, czy nie lepiej byłoby uświadamiać tych młodych chłopców (zdjęcia pokazują nastolatków), niż skazywać ich na publiczny lincz, a nawet konsekwencje sięgające poza rzeczywistość wirtualną. W gruncie rzeczy, zamiast zmniejszać ilość negatywnych zachowań w internecie, prowadzimy do ich eskalacji. Jednocześnie zwolennicy metody Tedego mogliby zauważyć, że mimo młodego wieku hejterzy to osoby zdolne już oceniać konsekwencje swoich słów i czynów, a jednorazowa kara tego typu może stanowić skuteczną nauczkę i przestrogę. Kwestia pozostaje otwarta, a podobne sposoby walki z hejtem zdają się zyskiwać na popularności.

\section{Przypadek nr 7 - artykuł na Strajk.eu}

O ile w przypadku kontrowersyjnego rapera, którego twórczość — według niego samego - skierowana jest do mało wymagającej publiczności, metoda opisywana powyżej raczej nie dziwi, to po serwisie, który przedstawia się jako „strona startowa polskiej lewicy" mamy prawo spodziewać się bardziej subtelnych sposobów działania. Najwyraźniej aktywiści stwierdzili, że walka z nienawiścią uświęca wszystkie środki. Swoje działania skierowali przeciwko osobom szerzącym mowę nienawiści wobec muzułmanów, określając je jako piewców „polskiego neohitleryzmu”. Akcja firmowana jest przez kilka środowisk, m.in. Ośrodek Monitorowania Zachowań Rasistowskich i Ksenofobicznych oraz Grecja w Ogniu. Gromadzą one 
wypowiedzi hejterów, opatrują je zdjęciem autorów oraz imieniem i nazwiskiem, a następnie publikują na opisywanej stronie, nie dokonując oczywiście anonimizacji wizerunku. Faktycznie, przytaczane wypowiedzi mogą wprawić w osłupienie, ale autorzy akcji również zdają się pałać nienawiścią, tym razem do swoich rodaków, co wyraża się m.in. w stwierdzeniu, że obozy zagłady były polskie, a nie niemieckie, czy porównywaniu Dmowskiego do Hitlera (Polscy internauci i ich stosunek do uchodźców... 2015). Jednocześnie niektóre wypowiedzi mają charakter żartu, sygnalizowanego np. poprzez emotikony, co czyni piętnowanie autorów na równi z prawdziwymi nienawistnikami raczej nieuprawnionym. Na szczęście więcej trzeźwości umysłu zachowują internauci odwiedzający witrynę i zostawiający komentarze pod rzeczonym wpisem. Ich reakcje są jednoznaczne: bunt przeciwko coraz liczniejszym migracjom wyznawców islamu (wraz z konsekwencjami) i podwójnej moralności ma swoje uzasadnienie, nawet jeżeli sprzeciw jest niekiedy wyrażany w mało wyważony sposób. Wytknięty zostaje całkowity brak obiektywizmu, zaślepienie „lewacką” ideologią i brak znajomości historii. Jak widać, według użytkowników sieci nie zawsze słuszne jest hasło, że cel uświęca środki, a walka $\mathrm{z}$ hejtem nie powinna sięgać po metody, które stawiają nas na równi z osobami, których zachowania potępiamy.

\section{Przypadek nr 8 - materiał wideo autorstwa Krzysztofa Gonciarza}

Kolejny przykład, którym chciałam się posłużyć, nie jest w pełni samodzielnym działaniem, ale częścią akcji organizowanej przez Fundację Batorego „Stop mowie nienawiści”. Opiera się ona na różnych formach wypowiedzi blogerów, którzy potępiają negatywne zachowania w sieci. Jej celem jest pokazanie, że internetowi twórcy, będący swego rodzaju autorytetem dla młodzieży, potępiają tego typu zachowania. Jednak większość wypowiedzi vlogerów jest pozbawiona wyrazu i skonstruowana w sposób, który drastycznie zmniejsza możliwość dotarcia do adresata. Mimo wszystko w tym gronie na uwagę zasługuje Krzysztof Gonciarz, youtuber znany jako The Beeczka, który z właściwą sobie swadą nagrał dziewięciominutowy materiał dający wyraz jego niechęci do wszelkiego rodzaju hejtu (MOWA NIENAWIŚCI - Zapytaj Beczkę... 2015). Co istotne, nie stara on się przekonać o szkodliwości takich zachowań, tylko w bezlitosny sposób je ośmiesza, przytaczając konkretne przykłady komentarzy hejterów ze swojego kanału czy kont na serwisach społecznościowych. Jako młody człowiek, świetnie poruszający się w sieci i znający zasady jej działania, jest w stanie przyjąć metody, które skutecznie pozwalają dotrzeć do grupy docelowej. Co prawda i tutaj pojawia się pytanie, na 
ile przywoływane przez Gonciarza wypowiedzi są faktycznie szkodliwym hejtem, a na ile niegroźnymi, acz specyficznymi żartami. Pomijając jednak ewentualne wątpliwości, można uznać, że tego typu sposób działania ma największą szansę odnieść jakikolwiek skutek.

\section{Przypadek nr 9 - tweet Susan Carland}

Aby zakończyć omawianie tego nieprzyjemnego tematu pozytywnym akcentem, warto wspomnieć o prywatnej akcji Susan Carland, Australijki, która postanowiła działać w myśl zasady „zło dobrem zwyciężaj”. Ze względu na fakt, że jest muzułmanką, często otrzymywała nienawistne wiadomości komentujące jej religię, a nawet sugerujące, że jest terrorystką. Za pomocą Twittera ogłosiła, że nie chce walczyć $\mathrm{z}$ autorami tych wypowiedzi, lecz potraktować je jako szansę na szerzenie dobra ${ }^{15}$. W związku $\mathrm{z}$ tym postanowiła przekazywać darowiznę $\mathrm{w}$ wysokości jednego dolara na konto organizacji UNICEF za każdy przepełniony nienawiścią komentarz. W kolejnym tweecie informowała, że wpłaciła już ponad tysiąc dolarów. Sprawiła w ten sposób, że hejterzy, wbrew swoim intencjom, przyczyniali się do poprawy sytuacji potrzebujących dzieci (Muzułmanka walczy z hejterami... 2015).

Jak pokazuje powyższa analiza, katalog działań mających przeciwdziałać mowie nienawiści w sieci jest bogaty. Począwszy od kampanii społecznych organizowanych przez duże instytucje i finansowanych z pieniędzy rządowych lub unijnych, przez internetowe oddolne akcje, skończywszy na indywidualnych inicjatywach pojedynczych osób zmęczonych docierającą do nich ilością hejtu. Analiza dotyczy tylko wybranych przypadków, gdyż jest ich naprawdę wiele; zaczęło już nawet funkcjonować pojęcie „antyhejtu”. Starałam się wskazać przykłady dobrze obrazujące kierunki podejmowanych działań. Oczywiście nadal pozostaje w mocy pytanie, nie tyle o słuszność tych starań, ale o ich skuteczność. Jak wspomniałam na początku, hejterzy nie posługują się racjonalną logiką, a jedynym motywem ich działań jest potrzeba zaistnienia w zbiorowej świadomości, poprzez wyrządzanie krzywdy innym. Często spotykanym rodzajem przeciwdziałania jest zatem ignorowanie tego typu osób, gdyż zainteresowanie ich zachowaniem stanowi powód

15 Zob.: https://twitter.com/SusanCarland/status/656980086172725248 [dostęp: 14.11.2015]. 
do dalszej aktywności. Jeśli zaś sytuacja jest na tyle poważna, że możemy mówić o naruszeniu prawa, należy bezwzględnie zgłaszać takie akty, tym bardziej, że funkcjonują narzędzia umożliwiające to bez wstawania od komputera.

Nierzadko można trafić na opinie, że akcje typu „HejtStop” czy „Stop mowie nienawiści” nie przynoszą faktycznych rezultatów, a są jedynie pozornymi działaniami pozwalającymi na zarobienie pieniędzy organizatorom (UE bardzo chętnie finansuje takie inicjatywy), bez rzetelnej ewaluacji. Sądzę, że należałoby zapobiegać, zamiast leczyć, co oznacza w tym przypadku dbałość o odpowiednią edukację młodzieży, która zmniejszyłaby szansę na pojawienie się sfrustrowanych jednostek, próbujących wyładować swój żal za pomocą internetu. Autorzy zajmujący się zagadnieniem również wskazują na to, że kluczowym czynnikiem decydującym o zachowaniu jednostki nie jest anonimowość, ograniczona kontrola społeczna czy specyficzna sytuacja komunikacyjna, gdyż nie tłumaczy to w pełni incydentalnej skali zjawiska. Kluczowy jest raczej posiadany kapitał kulturowy - to potrzeby, przekonania i poziom kultury osobistej w głównej mierze decydują o tym, kto jest skłonny do używania przemocy werbalnej (Juza 2015: 40-41). Jednak jest to działanie długofalowe, którego rezultaty nie będą widoczne od razu. Pozostaje jednak nadzieja, że internet, jako medium młode i pozostające wciąż w fazie dynamicznego rozwoju, sam się niejako „ucywilizuje” i wypracuje mechanizmy samonaprawy.

\section{Bibliografia}

Bauer Zbigniew (2009), Polskie fora internetowe. Przykład „mowy nienawiści” czy "mowy agresji”? [w:] Komunikowanie (się) w świecie elektronicznym, M. Filiciak, G. Ptaszek (red.), Wydawnictwa Akademickie i Profesjonalne, Warszawa.

Bralczyk Jerzy, Mikuła Paulina, Witt Arlena (2015), Rozmowa: Czy w internecie komunikujemy się, Mówiąc Inaczej niż poza nim?, Blog Forum Gdańsk 2015, https://www.youtube.com/watch?v=ph1NlusPSCI [dostęp: 13.02.2016].

Dębska Hanna (2013), Mowa nienawiści a wolność słowa w internecie - w poszukiwaniu uniwersalnego rozwiązania. Uwagi na marginesie rozważań Jamesa Banksa [w:] Człowiek zalogowany, M. Wysocka-Pleczyk, B. Świeży (red.), Biblioteka Jagiellońska, Kraków. 
Himalaje hipokryzji. Jarosław Kuźniar twarza kampanii „Hejt Stop” (2015), http:// telewizjarepublika.pl/himalaje-hipokryzji-jaroslaw-kuzniar-twarza-kampaniihejt-stop, 26636.html [dostęp: 13.02.2016].

Internet World Stats, http://www.internetworldstats.com/stats.htm [dostęp: 29.12.2015].

Internetowa kultura obrażania? (2012), K. Krejtza (red.), Interactive Advertising Bureau, Polska Szkoła Wyższa Psychologii Społecznej oraz Ośrodek Przetwarzania Informacji, Warszawa.

Jarosław K. - Król Hejterów (2015), http://www.zelaznalogika.net/jaroslaw-k-krol-hejterow/ [dostęp: 13.02.2016].

„Jednego w rurkach mniej”. Szydercze profile i agresja wobec 14-latka, który popelnit samobójstwo, http://www.tvp.info/20712085/jednego-w-rurkach-mniej-szyderczeprofile-i-agresja-wobec-14latka-ktory-popelnil-samobojstwo [dostęp: 13.02.2016]. Juza Marta (2015), Hejterstwo w komunikacji internetowej: charakterystyka zjawiska, przyczyny i sposoby przeciwdziałania [w:] Profilaktyka społeczna i resocjalizacja, IPSIR, Warszawa.

Kampania „One shot is enough” w serwisie PetaPixel, http://petapixel. com/2015/10/02/ads-one-shot-with-a-smartphone-camera-can-kill/?utm_source=feedburner\&utm_medium=feed\&utm_campaign=Feed $\% 3 \mathrm{~A}+$ PetaPixel+\%28PetaPixel\%29 [dostęp: 03.10.2015].

Kampania „Stop mowie nienawiści”, http://stopmowienienawisci.pl/ [dostęp: 14.11.2015].

Klimczuk Andrzej (2013), Hipoteza Sapira-Whorfa - Przegląd argumentów zwolenników i przeciwników [w:] Kultura - Społeczeństwo - Edukacja, Wydawnictwo UAM, Poznań.

Komentarz co ja widzę 0_o (2015) [do:] Ryj Kuźniara walczy $z$ hejtem w sieci. Nagraj własna wersje (2015), http://www.tvn24.pl/kultura-styl,8/ryj-kuzniaradziennikarz-w-kampanii-spolecznej-hejtstop,598197.html [dostęp: 13.02.2016]. Komentarz Zając (2015) [do:] \#RyjKuźniara. Świetna akcja. Pomyśl, zanim kogoś oplujesz (2015) [w:] Newsweek.pl/forum, http://www.newsweek.pl/forum/ jaroslaw-kuzniar-w-akcji-hejt-stop-ryjkuzniara,0,2307766,192085872,czytaj. html?cid=374761 [dostęp: 13.02.2016].

Mowa nienawiści - raport $z$ badań sondażowych (2014), M. Bilewicza, M. Marchlewskiej, W. Sorala, M. Winiewskiego (red.), Fundacja im. Stefana Batorego, Warszawa.

MOWA NIENAWIŚCI - Zapytaj Beczkę \#113 (2015) [film], Krzysztof Gonciarz, https://www.youtube.com/watch?v=ITGB2skMCHM [dostęp: 14.11.2015]. 
Mowa nienawiści w internecie - jak z niq walczyć? (2013), D. Bychawskiej-Siniarskiej, D. Głowackiej (red.), Helsińska Fundacja Praw Człowieka, Warszawa. Muzułmanka walczy z hejterami. Za każdy złośliwy komentarz... odda dolara na rzecz dzieci (2015), http://natemat.pl/161745, muzulmanka-walczy-z-hejteramiza-kazdy-zlosliwy-komentarz-odda-dolara-na-rzecz-dzieci [dostęp: 14.11.2015]. Oficjalna strona akcji HejtStop, http://hejtstop.pl/ [dostęp: 30.12.2015].

Opis kampanii UNICEF, http://www.cosmopolitan.pl/w-twoim-swiecie/5989/ one-shot-is-enough-bardzo-mocna-kampania-unicef [dostęp: 10.11.2015].

Polscy internauci i ich stosunek do uchodźców - kolejne fakty (2015), http://strajk.eu/ polscy-internauci-i-ich-stosunek-do-uchodzcow-kolejne-fakty/ [dostęp: 02.01.2016]. Portret internauty, http://biblioteka.mwi.pl/index.php?option=com_k2\&view=item\&task=download\&id=150\&Itemid=3. [dostęp:13.02.2016].

Pyżalski Jacek (2012), Agresja elektroniczna i cyberbullying jako nowe ryzykowne zachowania młodzieży, Oficyna Wydawnicza „Impuls”, Kraków.

Społeczna percepcja przemocy werbalnej mowy nienawiści - raport z badań(2007), M. Feliksiaka (red.), CBOS, Warszawa.

Trollowanie [w:] Wikipedia: Wolna encyklopedia, https://pl.wikipedia.org/wiki/ Trollowanie [dostęp: 28.12.2015].

Wallace Patricia (2003), Psychologia internetu, Rebis, Poznań.

Włodarczyk Joanna (2014), Mowa nienawiści w internecie $w$ doświadczeniu polskiej młodzieży [w:] Dziecko krzywdzone. Teoria, badania, praktyka, Fundacja Dzieci Niczyje, Warszawa.

Wpisy Tedego otagowane \#zobacz mojego hejtera, https://instagram.com/p/8vLdTXCrpQ/?tagged=zobacz_mojego_hejtera [dostęp:14.11.2015].

Wykop.pl nie będzie tolerowat mowy nienawiści i agresji (2015), Mikroblog: http://www.wykop.pl/link/2767367/wykop-pl-nie-bedzie-tolerowal-mowynienawisci-i-agresji/ [dostęp: 10.11.2015].

You look disgusting (2015) [film], My Pale Skin, https://www.youtube.com/watch?v=WWTRwj9t-vU [dostęp: 09.11.2015]. 


\title{
Aleksandra Wysokińska
}

\section{Hejtowanie hejterów, czyli jak radzimy sobie z mową nienawiści w internecie}

\author{
Hating the Haters - How We Handle Hate Speech in the Internet
}

Słowa kluczowe: hejt, hejter, mowa nienawiści, internet, media społecznościowe Key words: hate speech, hater, internet, social media, social campaign

\section{Streszczenie}

W ostatnim czasie jesteśmy świadkami rosnącej popularności zjawiska społeczno-kulturowego określonego mianem „hejtu”. Stał się on tematem niezwykle medialnym i nośnym, a każda akcja rodzi reakcję. Z czasem zaczęły się pojawiać inicjatywy mające na celu potępienie, napiętnowanie lub po prostu zwrócenie uwagi na problem. Artykuł ma na celu prezentację różnych prób przeciwdziałania zjawisku hejterstwa w sieci na wybranych przykładach. Została omówiona również ich recepcja, zarówno wśród użytkowników, jak i mediów opiniotwórczych. Autorka dokonała także ich socjologicznej analizy.

\begin{abstract}
Nowadays, we are witnessing the growing popularity of social and cultural phenomenon known as "Internet hate". It has become a very catchy topic willingly taken up by media. And it is known that every action generates a reaction. Thus, over time, various initiatives, aimed at condemnation, criticizing or simply drawing attention to the issue began to appear. Article aims to present selected examples of diverse attempts to resist phenomenon of the hating in the Internet. It also discusses their reception among both users and opinion-forming media. The author also seeks to make their sociological analysis.
\end{abstract}

